\title{
Land use change and the impact on greenhouse gas exchange in north Australian savanna soils
}

\author{
S. P. P. Grover ${ }^{1, *}$, S. J. Livesley ${ }^{2}$, L. B. Hutley ${ }^{1}$, H. Jamali ${ }^{2}$, B. Fest ${ }^{2}$, J. Beringer ${ }^{3}$, K. Butterbach-Bahl ${ }^{4}$, and \\ S. K. Arndt ${ }^{2}$ \\ ${ }^{1}$ Research Institute for the Environment and Livelihoods, Charles Darwin University, NT, 0909, Australia \\ ${ }^{2}$ Department of Forest and Ecosystem Science, The University of Melbourne, VIC, Australia \\ ${ }^{3}$ School of Geography and Environmental Science, Monash University, VIC, 3800, Australia \\ ${ }^{4}$ Institute for Meteorology and Climate Research, Karlsruhe Institute of Technology, Kreuzeckbahnstr., 19, \\ 82467 Garmisch-Partenkirchen, Germany \\ *now at: Department of Civil Engineering, Monash University, VIC, 3800, Australia
}

Correspondence to: S. P. P. Grover (sam.grover@monash.edu)

Received: 28 June 2011 - Published in Biogeosciences Discuss.: 8 September 2011

Revised: 15 December 2011 - Accepted: 30 December 2011 - Published: 25 January 2012

\begin{abstract}
Savanna ecosystems are subjected to accelerating land use change as human demand for food and forest products increases. Land use change has been shown to both increase and decrease greenhouse gas fluxes from savannas and considerable uncertainty exists about the non- $\mathrm{CO}_{2}$ fluxes from the soil. We measured methane $\left(\mathrm{CH}_{4}\right)$, nitrous oxide $\left(\mathrm{N}_{2} \mathrm{O}\right)$ and carbon dioxide $\left(\mathrm{CO}_{2}\right)$ over a complete wetdry seasonal cycle at three replicate sites of each of three land uses: savanna, young pasture and old pasture (converted from savanna 5-7 and 25-30 yr ago, respectively) in the Douglas Daly region of Northern Australia. The effect of break of season rains at the end of the dry season was investigated with two irrigation experiments.

Land use change from savanna to pasture increased net greenhouse gas fluxes from the soil. Pasture sites were a weaker sink for $\mathrm{CH}_{4}$ than savanna sites and, under wet conditions, old pastures turned from being sinks to a significant source of $\mathrm{CH}_{4}$. Nitrous oxide emissions were generally very low, in the range of 0 to $5 \mu \mathrm{g} \mathrm{N}_{2} \mathrm{O}-\mathrm{N} \mathrm{m}^{-2} \mathrm{~h}^{-1}$, and under dry conditions soil uptake of $\mathrm{N}_{2} \mathrm{O}$ was apparent. Break of season rains produced a small, short lived pulse of $\mathrm{N}_{2} \mathrm{O}$ up to $20 \mu \mathrm{g} \mathrm{N} \mathrm{N}_{2} \mathrm{O}-\mathrm{N} \mathrm{m}^{-2} \mathrm{~h}^{-1}$, most evident in pasture soil. Annual cumulative soil $\mathrm{CO}_{2}$ fluxes increased after clearing, with savanna (14.6 $\left.\mathrm{t} \mathrm{CO}_{2}-\mathrm{C} \mathrm{ha}^{-1} \mathrm{yr}^{-1}\right)$ having the lowest fluxes compared to old pasture $\left(18.5 \mathrm{t} \mathrm{CO}_{2}-\mathrm{C} \mathrm{ha}^{-1} \mathrm{yr}^{-1}\right)$ and young pasture $\left(20.0 \mathrm{tCO}_{2}-\mathrm{Cha}^{-1} \mathrm{yr}^{-1}\right)$. Clearing savanna increased soil-based greenhouse gas emissions from 53 to
\end{abstract}

$\sim 70 \mathrm{t} \mathrm{CO}_{2}$-equivalents, a $30 \%$ increase dominated by an increase in soil $\mathrm{CO}_{2}$ emissions and shift from soil $\mathrm{CH}_{4}$ sink to source. Seasonal variation was clearly driven by soil water content, supporting the emerging view that soil water content is a more important driver of soil gas fluxes than soil temperature in tropical ecosystems where temperature varies little among seasons.

\section{Introduction}

It is widely accepted that the increasing atmospheric concentrations of the greenhouse gases carbon dioxide $\left(\mathrm{CO}_{2}\right)$, methane $\left(\mathrm{CH}_{4}\right)$ and nitrous oxide $\left(\mathrm{N}_{2} \mathrm{O}\right)$ are warming the Earth's climate (IPCC, 2007). Fossil fuel use and land use are the two key processes driving the increase in concentration of these three greenhouse gases (Houghton, 2007). While fossil fuel use and resultant emissions are relatively easy to measure and model, fluxes of greenhouse gases from land use, either modified agricultural systems or natural ecosystems, are more difficult due to their spatial and temporal variability and our limited understanding of the processes controlling these fluxes. While $\mathrm{CH}_{4}$ and $\mathrm{N}_{2} \mathrm{O}$ are present in the atmosphere in smaller concentrations than $\mathrm{CO}_{2}$, their greenhouse warming potentials are much greater $\left(\mathrm{CH}_{4} 25\right.$ times, $\mathrm{N}_{2} \mathrm{O}$ 296 times) (IPCC, 2007). Considerable progress has been 
made with regards to $\mathrm{CO}_{2}$, but $\mathrm{CH}_{4}$ and $\mathrm{N}_{2} \mathrm{O}$ have only just begun to be incorporated into global climate models (Arneth et al., 2010). For national accounting purposes, non- $\mathrm{CO}_{2}$ greenhouse gas emissions from agricultural areas are often simply estimated using standard IPCC emission factors as a function of soil type, tillage or as a fraction of fertiliser added. Predicting emissions from natural or managed systems on the ancient, leached north Australian soils using such an approach may lead to unreliable estimates, given the low $\mathrm{N}$ and $\mathrm{C}$ content. Given increasing interest in improved land use and agricultural practices to reduce greenhouse gas emissions, data describing soil-derived fluxes of $\mathrm{CO}_{2}$ and non$\mathrm{CO}_{2}$ gases and their drivers are required. Such data can also be incorporated into process based models describing fluxes as a function of environmental drivers and land use. The DNDC (denitrification-decomposition) suite of models ( $\mathrm{Li}$, 2007) or DAYCENT (Del Grosso et al., 2006) are capable of simulating these soil derived emissions for different soil and climate types, vegetation cover and management. Initially designed for agricultural application, enhanced versions have been developed and applied to forest (Forest-DNDC) and wetland ecosystems (Giltrap et al., 2010). When calibrated with region specific data such models can play a role in land use scenarios for mitigation purposes and even verification of emissions at property scales. However, without a robust basis for estimating flux based on observations for various land use scenarios, mitigation schemes will have less value.

Changes in land use are occurring continuously, all over the Earth and are associated with a change in the greenhouse gas fluxes from the land. Afforestation of improved pastures in Western Australia significantly decreased soil $\mathrm{N}_{2} \mathrm{O}$ emissions and increased soil $\mathrm{CH}_{4}$ uptake (Livesley et al., 2009). Conversely, it may be anticipated that deforestation might increase soil $\mathrm{N}_{2} \mathrm{O}$ emissions and decrease the capacity of soils to oxidize atmospheric $\mathrm{CH}_{4}$. Deforestation is likely to increase in the tropical savanna woodlands of Northern Australia, as prolonged drought in the south prompts agricultural producers to look north in search of water and soil resources (Petheram and Bristow, 2008; Bowman et al., 2010). In a review of $\mathrm{N}_{2} \mathrm{O}$ and $\mathrm{CH}_{4}$ fluxes from savanna soils under different land uses world-wide, Castaldi et al. (2006) found that, compared to natural systems, in managed systems the soils' ability to act as a $\mathrm{CH}_{4}$ sink was decreased, while no statistically significant effect upon $\mathrm{N}_{2} \mathrm{O}$ fluxes could be found. Both land use and rainfall affected $\mathrm{N}_{2} \mathrm{O}$ fluxes from savanna soils in Senegal (Dick et al., 2006), with increased $\mathrm{N}_{2} \mathrm{O}$ emissions associated with heavy (simulated) rainfall and the presence of $\mathrm{N}$-fixing tree species.

Savannas cover one sixth of the Earth's surface and are subject to accelerating land use change (Grace et al., 2006). However, data on greenhouse gas fluxes from savannas is scarce in comparison with other ecosystems. In Australia, savanna covers a quarter of the country, and this is the most intact savanna ecosystem left in the world (Woinarski et al., 2007). A number of studies have described the carbon dy- namics of Australian savannas (Chen et al., 2002, 2003; Eamus et al., 2001; Beringer et al., 2003, 2007; Hutley and Beringer, 2010), and the greenhouse gas emissions from burning these ecosystems have also been quantified (RussellSmith et al., 2009). However, there is a lack of data on non$\mathrm{CO}_{2}$ greenhouse gas fluxes from these soils, and soil is the main source/sink of $\mathrm{CH}_{4}$ and $\mathrm{N}_{2} \mathrm{O}$. The first objective of this study was to describe the soil fluxes of $\mathrm{CH}_{4}, \mathrm{~N}_{2} \mathrm{O}$ and $\mathrm{CO}_{2}$ over an entire wet-dry seasonal cycle in uncleared tropical savanna woodland (savanna) and from improved pastures. Measurements were made at sites cleared between 5 and 7 years ago ("young pasture") and between 25 and 30 years ago ("old pasture"). The second objective of this study was to assess the impact of "break of season" rains on $\mathrm{N}_{2} \mathrm{O}$ and $\mathrm{CH}_{4}$ fluxes, speculating here that these rainfall events may be linked to significant pulse emissions (Borken and Matzner, 2008). The third objective was to investigate the environmental drivers that influence greenhouse gas fluxes from savanna soils, with the aim of developing relationships that can be used to model greenhouse gas fluxes across the savanna biome as a function of land use and environmental conditions.

\section{Methods}

To address these objectives, we took an integrated approach combining a number of different methods. Manual chambers were used to measure greenhouse gas fluxes over the entire wet dry cycle (September 2007-November 2008), at three replicate sites for each land use (savanna, young and old pasture). This spatially replicated but temporally coarse data set was augmented by two experiments. The first experiment utilised an automated chamber system, which has a temporal resolution of $4 \mathrm{~h}$, and an artificial irrigation simulating break of season rains. The second experiment utilised the inert tracer gas $\mathrm{SF}_{6}$ for studying soil gas diffusion, and two artificial rainfall treatments. These experiments addressed the second objective, and justified the manual chamber resampling period of 6 weeks. The third objective involved recording potential environmental drivers during the manual and automated chamber sampling and statistical analysis. Continuous recording of some potential environmental drivers of soil greenhouse gas fluxes also occurred at nearby flux tower sites.

\subsection{Site description}

The Douglas Daly region of the Northern Territory was chosen for this study, as this catchment is dominated by savanna but, due to suitable climate and soil conditions, is also the focus for expanding agriculture (Bowman et al., 2010) and forestry. Land clearing for agriculture in the region began shortly after the Northern Territory became selfgoverning in 1978 (Chapman et al., 1996). The Agricultural 
Development and Marketing Authority (ADMA) cleared land and allocated farms of 4000-6000 ha to six farmers in 1980. The past two decades have seen numerous subdivisions and significant further land clearing and, recently, the addition of small areas of irrigated cropping and plantation forestry ( $\sim 10000$ ha and expanding).

The climate of the Douglas Daly region is typical of the wet-dry tropics. The mean annual maximum and minimum temperatures are $34.2^{\circ} \mathrm{C}$ and $19.6^{\circ} \mathrm{C}$. At 09:00 am, the annual mean relative humidity is $70 \%$. The area receives an annual average of $1177 \mathrm{~mm}$ of rain, which falls on just 66 days, predominantly between December and March (Bureau of Meteorology). The dominant vegetation of the region is savanna, an ecosystem consisting of a continuous or near continuous $\mathrm{C} 4$ grass dominated understorey, with a discontinuous woody overstorey (Hutley and Setterfield, 2008). Savanna vegetation is adapted to frequent fire and a highly seasonal rainfall distribution, with rapid growth during the 5 month wet season and low growth or dormancy during the dry season (Bowman et al., 2010). The vegetation at the savanna site is dominated by the tree species Eucalyptus tetrodonta, Corymbia latifolia and Terminalia grandiflora, with the understorey vegetation dominated by the grasses Sorghum spp. and Heteropogon contortus.

Nine sites were chosen to provide three replicates of each land use: savanna, young pasture and old pasture. The sites were all on the same soil type; Red Kandosol (Isbell, 2002), and originally supported the same vegetation community. At six of the sites, the savanna was cleared (vegetation felled by chains, then burnt) and pasture was sown between 25 and $30 \mathrm{yr}$ ago (old pasture) or between 5 and $7 \mathrm{yr}$ ago (young pasture). The pastures have all been grazed by beef cattle at low stocking rates and sporadically fertilized. The pastures now support a range of grasses including H. contortus, Digitaria eriantha, Pennisetum pedicellatum, Chloris spp. and Eragrostis spp. and leguminous species including Senna obtusifolia. For site locations see Fig. 1, and for further site details see Table 1.

\subsection{Seasonal and spatial variation in soil gas exchange}

The manual closed chamber method (Hutchinson and Mosier, 1981) was used to quantify the spatial and seasonal variation in soil-atmosphere exchange of $\mathrm{CO}_{2}, \mathrm{CH}_{4}$ and $\mathrm{N}_{2} \mathrm{O}$ in the three land uses: savanna, young pasture and old pasture (at three replicate sites for each land use). Manual chambers were made up of a light grey PVC pipe (diameter $25 \mathrm{~cm}$, height $24.5 \mathrm{~cm}$, volume 12.01 , basal area $0.049 \mathrm{~m}^{2}$ ) with a twist-lid (PVC) incorporating a butyl-rubber septum and a rubber O-ring to form a gas tight seal. Manual chamber bases were installed at least one hour before lid closure. Five chambers were installed at each site, on each measurement occasion (19/09/07, 26/11/07, 14/01/08, 28/2/08, 8/05/08, 23/06/08, 11/11/08). Measuring gas flux at each of the 9 sites could take up to four days to complete and all gas flux measures were made between 08:00 and 16:00 h LT. The litter layer was cut around the circumference of each chamber base and the chambers were inserted $2 \mathrm{~cm}$ into the soil surface. Grass was avoided where possible, but some chambers did contain small amounts of grass foliage. The internal height of each manual chamber was carefully measured so as to calculate the headspace volume of each chamber. Once the manual chamber lids were attached and twist-sealed, $15 \mathrm{ml}$ headspace gas samples were taken at $0,20,40$ and $60 \mathrm{~min}$ after closure using a $20 \mathrm{ml}$ syringe (Terumo ${ }^{\mathrm{TM}}$ USA) and a one-way stopcock. Gas samples were stored in pressurized exetainers (Labco Ltd., UK) which were usually analysed within 20 days for $\mathrm{N}_{2} \mathrm{O}$ and $\mathrm{CH}_{4}$ by gas chromatography (Schimadzu GC17A). Previous work demonstrated no change in concentrations with storage over this time. Injection of a single gas sample filled two $2.0 \mathrm{ml}$ sample loops, one leading to a flame ionisation detector for determination of $\mathrm{CH}_{4}$ concentration and one leading to an electron capture detector for determination of $\mathrm{N}_{2} \mathrm{O}$ concentration. Exetainers were stored in a cool, dark container and over-pressurised ( $20 \mathrm{ml}$ in $12 \mathrm{ml}$ container volume) to ensure any minor leaks were from the exetainers to the bulk air. Soil $\mathrm{N}_{2} \mathrm{O}$ and $\mathrm{CH}_{4}$ fluxes were calculated from the linear increase or decrease in concentration with time, since a linear regression was best suited to describe temporal changes in chamber head space concentrations. Soil $\mathrm{CO}_{2}$ emission rates were measured after headspace gas sample collection was complete, using an Infra-red gas analyser (IRGA) (EGM, PP-Systems ${ }^{\mathrm{TM}}$, UK). The individual manual chamber lids were removed and the chambers vented. A two port chamber lid was then attached and the linear increase in $\mathrm{CO}_{2}$ concentration instantaneously measured between 90 and $180 \mathrm{~s}$ after lid closure using the IRGA in a closed dynamic setup. Soil temperature $(3 \mathrm{~cm})$ and soil water content were measured at each chamber.

\subsection{Environmental drivers: soil sampling and measurements}

Soil was sampled from each chamber using soil cores $(\varnothing$ $72 \mathrm{~mm}$ ) to determine bulk density $(0-5 \mathrm{~cm})$. Soil samples were transferred immediately to an ice box and then stored refrigerated for 1 to 4 days prior to analysis. The soil samples were weighed, and subsamples were removed for analysis of gravimetric water content and soil $\mathrm{NO}_{3}^{-}$and $\mathrm{NH}_{4}^{+}$. Soil samples were extracted with $1 \mathrm{M} \mathrm{KCl}(1: 4$, soil: $\mathrm{KCl})$ and shaken for one hour on a wrist shaker, then filtered (Whatman 42) and frozen prior to analysis of $\mathrm{NO}_{3}^{-}$and $\mathrm{NH}_{4}^{+}$on a Technicon $^{\mathrm{TM}}$ Auto-analyser. Gravimetric water content was determined through oven drying at $105^{\circ} \mathrm{C}$ for $48 \mathrm{~h}$. The remaining soil was air-dried and stored for $\mathrm{C}$ and $\mathrm{N}$ measurements. A sub-sample of each air-dried soil sample was analysed for total $\mathrm{C}$ and $\mathrm{N}$ content using an elemental analyser (EuroEA 3028HT, EuroVector SpA, Milan, Italy) connected to an isotope ratio mass spectrometer (IsoPrime, GV Instruments, Manchester, UK). 
Table 1. Site details from the manual chamber sites. Soil samples were taken from $0-10 \mathrm{~cm}$, values are the average of triplicate samples.

\begin{tabular}{|c|c|c|c|c|c|c|c|c|c|c|}
\hline Land use & Vegetation & Soil type & $\begin{array}{l}\mathrm{BD} \\
\left(\mathrm{g} \mathrm{cm}^{-3}\right)\end{array}$ & $\mathrm{pH}$ & $\mathrm{EC}$ & $\begin{array}{r}\mathrm{C} \\
\left(\mu \mathrm{S} \mathrm{cm}^{-1}\right)\end{array}$ & $\begin{array}{l}\mathrm{N} \\
\%\end{array}$ & $\begin{array}{r}\mathrm{CEC} \\
\%\end{array}$ & $\begin{array}{r}\text { Bray P } \\
\left(\mathrm{mg}^{-1}\right)\end{array}$ & $\left(\mathrm{mg}^{-1}\right)$ \\
\hline A & savanna & $\begin{array}{l}\text { Eucalyptus tetrodonta, Corymbia latifolia, Erythrophleum, chlorostachys and Acacia sp. } \\
\text { over a mid to tall tussock grassland of Sorghum spp. and Heteropogon spp. } \\
\text { woodland with a sparse mid stratum of E. chlorostachys, E. tetradonta, Terminalia canescens }\end{array}$ & $\begin{array}{l}\text { Red } \\
\text { Kandosol }\end{array}$ & 1.52 & 6.67 & 0.01 & 0.48 & 0.02 & 41.3 & 0.28 \\
\hline $\mathrm{D}$ & savanna & Eucalyptus tetradonta, Eucalyptus miniata, Sorghum spp., Heteropogon contortus & $\begin{array}{l}\text { Red } \\
\text { Kandosol }\end{array}$ & 1.45 & 6.34 & 0.01 & 0.66 & 0.04 & 41.3 & 0.15 \\
\hline \multirow[t]{2}{*}{ G } & & Eucalyptus tetradonta, Eucalyptus miniata, Sorghum spp., Heteropogon contortus & $\begin{array}{l}\text { Red } \\
\text { Kandosol }\end{array}$ & 1.34 & 7.02 & 0.02 & 0.53 & 0.04 & 54.8 & 0.21 \\
\hline & $\begin{array}{l}\text { average } \\
\text { savanna }\end{array}$ & & & 1.44 & 6.68 & 0.01 & 0.56 & 0.03 & 45.8 & 0.21 \\
\hline B & $\begin{array}{l}\text { young } \\
\text { pasture }\end{array}$ & $\begin{array}{l}\text { mixed tussock grassland of perennial and annual species including Sorghum spp., } \\
\text { Heteropogon contortus and Chrysopogon fallax with regrowth of cleared Eucalyptus tetradonta, } \\
\text { Eucalyptus miniata and a shrubby mid-stratum of Terminalia sp. and Acacia spp.\& }\end{array}$ & $\begin{array}{l}\text { Red } \\
\text { Kandosol }\end{array}$ & 1.50 & 6.51 & 0.01 & 0.65 & 0.03 & 51.2 & 0.66 \\
\hline E & $\begin{array}{l}\text { young } \\
\text { pasture }\end{array}$ & Jarrah grass, wincassia & $\begin{array}{l}\text { Red } \\
\text { Kandosol }\end{array}$ & 1.54 & 6.22 & 0.02 & 0.67 & 0.04 & 42.4 & 0.29 \\
\hline \multirow[t]{2}{*}{$\mathrm{H}$} & $\begin{array}{l}\text { young } \\
\text { pasture }\end{array}$ & $\begin{array}{l}\text { Heteropogan contortus, pennisetum pedicellum, sesamum indicum with regrowth of } \\
\text { cleared Eucalyptus tetradonta, Eucalyptus miniata }\end{array}$ & $\begin{array}{l}\text { Red } \\
\text { Kandosol }\end{array}$ & 1.51 & 6.65 & 0.02 & 0.87 & 0.06 & 86.4 & 1.45 \\
\hline & $\begin{array}{l}\text { average } \\
\text { young } \\
\text { pasture }\end{array}$ & & & 1.52 & 6.46 & 0.02 & 0.73 & 0.04 & 60.0 & 0.80 \\
\hline $\mathrm{C}$ & old pasture & Heteropogon contortus, Aristida spp. and other tussock grasses & $\begin{array}{l}\text { Red } \\
\text { Kandosol }\end{array}$ & 1.55 & 6.12 & 0.02 & 0.82 & 0.05 & 54.2 & 0.49 \\
\hline $\mathrm{F}$ & old pasture & Eragrostis spp., heteropogan contortus & $\begin{array}{l}\text { Red } \\
\text { Kandosol }\end{array}$ & 1.59 & 6.25 & 0.02 & 0.74 & 0.05 & 44.7 & 0.29 \\
\hline \multirow[t]{2}{*}{ I } & old pasture & Senna obtusifolia, Digitaria eriantha & $\begin{array}{l}\text { Red } \\
\text { Kandosol }\end{array}$ & 1.48 & 5.71 & 0.02 & 0.98 & 0.07 & 51.0 & 0.30 \\
\hline & $\begin{array}{l}\text { average old } \\
\text { pasture }\end{array}$ & & & 1.54 & 6.03 & 0.02 & 0.85 & 0.06 & 50.0 & 0.36 \\
\hline
\end{tabular}

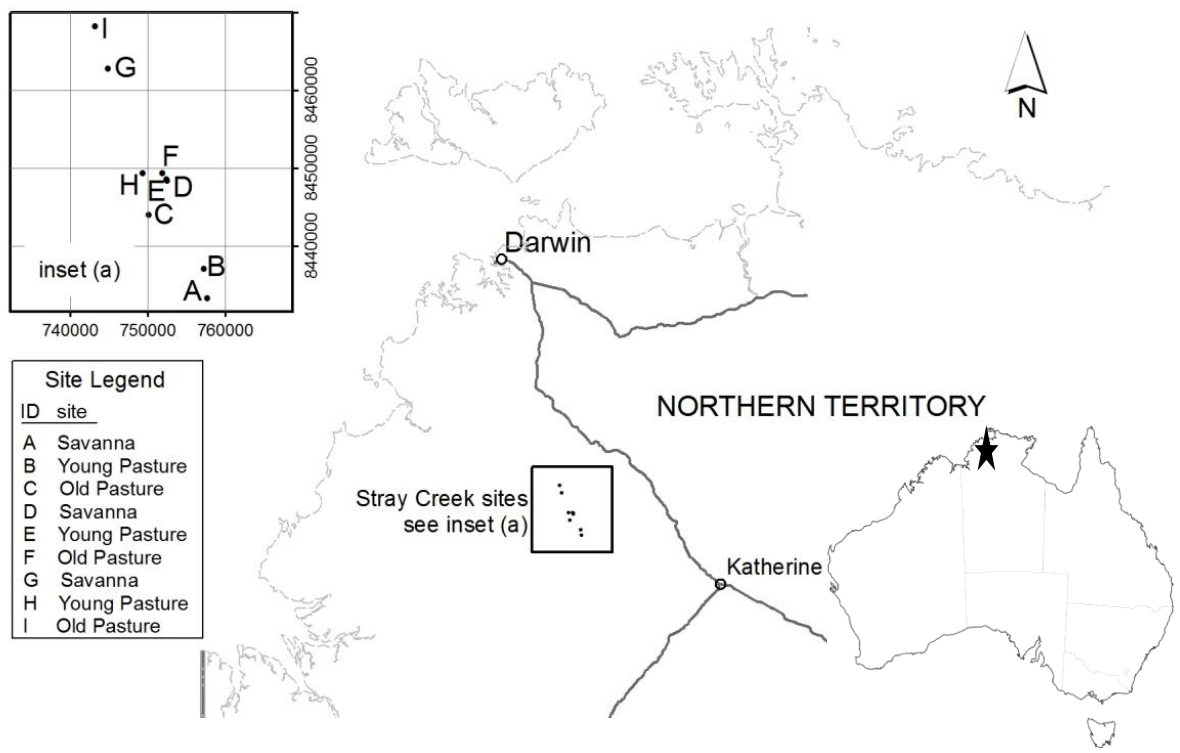

Fig. 1. Regional map of the Douglas-Daly region in the Northern Territory of Australia, showing the locality of the nine field sites; three savanna woodlands, three young pastures and three old pastures. The star shows the location on the continental map of Australia.

\subsection{Environmental drivers: soil N mineralisation}

Soil nitrification and ammonification were estimated by direct incubation of nylon mesh bags containing $4 \mathrm{~g}$ of ion exchange resin beads (MTO -Dowex Marathon MR-3) at a depth of $\sim 5 \mathrm{~cm}$. Three replicate resin bags were buried at each of the 9 sites on 6 occasions. The resin bags were collected after 45 to 142 days and stored refrigerated until extraction. Total exchangeable ions were extracted from the resin with four repeat $1 \mathrm{M} \mathrm{KCl}$ washes $(1: 25$, resin: $\mathrm{KCl})$, that were frozen prior to analysis for $\mathrm{NO}_{3}^{-}$and $\mathrm{NH}_{4}^{+}$concentration on a Technicon ${ }^{\mathrm{TM}}$ segmented flow auto-analyser. 


\subsection{Break of season rains Experiment 1: continuous soil trace gas exchange measurements}

Trace gas flux was measured continuously for twelve days between 12 September 2007 and 26 September 2007 (the end of the dry season) using an automated trace gas measurement system (Breuer et al., 2002), consisting of a gas chromatograph (GC, SRITM, Torrance, CA, USA) linked to ten clear acrylic chambers (six 30.41 chambers, two 37.51 chambers and two 21.61 chambers) with lids that open and close automatically through pneumatic piston control. Five chambers were installed in the savanna and the other five chambers were installed in the adjacent young pasture. Chamber bases were driven approximately $5 \mathrm{~cm}$ into the soil several days before measurements began. Chambers were attached to a base using clamps and closed cell foam.

To measure trace gas flux, five of the ten chambers would close for $2 \mathrm{~h}$, then these chambers (1-5) would open and the other chambers (6-10) would close. As such, each automated chamber was measured six times within a $24 \mathrm{~h}$ period. During chamber closure, four air samples $(\sim 0.51 \mathrm{each})$ were withdrawn at equal time intervals from each closed chamber. Each air sample took four minutes to withdraw. Chambers are not entirely airtight and thus air is drawn in from outside (rather than sucked out of the soil) to compensate for air removed in the sample line. This has been ascertained in previous work with these chamber systems (Rosenkranz et al., 2006), as underpressure was never measured while taking samples. Towards the end of each four minute air sample withdrawal, two $3 \mathrm{ml}$ sub-samples of the sample air were collected and passed into the $\mathrm{GC}$ for measurement of $\mathrm{N}_{2} \mathrm{O}$ concentration using a ${ }^{63} \mathrm{Ni}$ electron capture detector (ECD) and $\mathrm{CH}_{4}$ concentration using a flame ionisation detector (FID). The GC was calibrated with certified standard gas (Air Liquide ${ }^{\mathrm{TM}}$, USA) every $30 \mathrm{~min}$. From the four $\mathrm{N}_{2} \mathrm{O}$ and $\mathrm{CH}_{4}$ concentration measurements during a $2 \mathrm{~h}$ period of closure, a linear regression and therefore flux was calculated. For each chamber, six flux measurements were made during a $24 \mathrm{~h}$ period, one every $4 \mathrm{~h} . \mathrm{CO}_{2}$ was measured during the experiment but not recorded due to instrument malfunction. Soil water content $(0-6 \mathrm{~cm})$ and soil temperature (at $5 \mathrm{~cm}$ depth) were continually measured using "standing wave" soil moisture probes (MP406) and temperature sensors attached to a weather station (Tain ${ }^{\mathrm{TM}}$ electronics) in the savanna and in the pasture (data not shown). Soil water content was also measured manually by taking soil cores.

The minimum detectable limit (MDL) for this automated trace gas system was calculated as:

$\mathrm{MDL}=2 \cdot \mathrm{SD} \cdot V /(A \cdot T)$

where SD is the standard deviation of the gas concentration in ambient air, $V$ is the volume of the chamber $(\mathrm{L})$, $A$ is the area of soil under the chamber $\left(\mathrm{m}^{2}\right)$ and $T$ is the time for incubation (hour). This is then corrected to flux $\left(\mu \mathrm{g} \mathrm{m}^{-1} \mathrm{~h}^{-1}\right.$ ) using the ideal gas law and atom/molecular mass. The MDL for $\mathrm{N}_{2} \mathrm{O}$ was $1.35 \mu \mathrm{g} \mathrm{N} \mathrm{m}^{-2} \mathrm{~h}^{-1}$ and for $\mathrm{CH}_{4}$ was $2.88 \mu \mathrm{g} \mathrm{C} \mathrm{m}{ }^{-2} \mathrm{~h}^{-1}$.

On 21 September 2007 all chambers were irrigated with $40 \mathrm{~mm}$ of water over $20 \mathrm{~min}$, to simulate break-of-season rains. One meter square quadrats were also irrigated, in both the savanna and the pasture, from which soils cores were collected to measure soil water content 1,3 and 5 days after the irrigation event. Two soil pits were dug to $50 \mathrm{~cm}$ depth in the savanna and the pasture, adjacent to the chambers. Soil cores were taken to measure bulk density and soil water content ( $5 \mathrm{~cm}$ cores at $5,15,30$ and $45 \mathrm{~cm}$ depth).

\subsection{Break of season rains Experiment 2: soil gas diffusivity}

In the dry season of 2009 on 1st July, soil gas diffusion was measured at contrasting water contents. The method followed von Fischer et al. (2009) and uses sulphur hexa fluoride $\left(\mathrm{SF}_{6}\right)$ as a tracer to estimate soil gas diffusion. A $12 \mathrm{ml}$ volume of $\mathrm{SF}_{6}$ was injected into a manual chamber headspace and the decrease in concentration monitored over $30 \mathrm{~min}$. Three contrasting soil moisture contents were established: (1) dry soil (not irrigated), (2) medium soil moisture $\left(501 \mathrm{~m}^{-2}\right.$ added one day before) and (3) wet soil moisture $\left(501 \mathrm{~m}^{-2}\right.$ added one day before and $201 \mathrm{~m}^{-2}$ added in the hour before). Three replicate gas flux and diffusion measurements were made in each water treatment (dry, medium, wet) at each of the three land uses (savanna, young pasture, old pasture). The $20 \mathrm{ml}$ gas samples were taken from the chamber headspace at 2, 12, 22 and $32 \mathrm{~min}$ after chamber closure using a $20 \mathrm{ml}$ syringe (Terumo, USA) and a one-way stopcock. No sampling in the initial two minutes enabled equilibration and good mixing of $\mathrm{SF}_{6}$. Gas samples were immediately transferred and stored in pre-evacuated exetainers and analysed for $\mathrm{CH}_{4}$ and $\mathrm{N}_{2} \mathrm{O}$ concentration as described in Sect. 2.2 for manual chamber measurements.

\subsection{Data analysis and presentation}

Continuous fluxes are the average values from 5 chambers. Manual fluxes are the average of 15 chambers ( 5 chambers at each of three replicate sites). Data from the manual chamber measurements were not normally distributed, so the following transformations were applied to normalise their distribution: $\mathrm{CO}_{2} \mathrm{LN}$ (value), $\mathrm{CH}_{4} \mathrm{LN}(\mathrm{LN}$ (value +100$), \mathrm{N}_{2} \mathrm{O}$ $\mathrm{LN}(\mathrm{LN}$ value +10$)$. Statistical significance was defined as difference at the $95 \%$ level (i.e. $p \leq 0.05$ ). Differences between land uses and the effect of seasonality were investigated for each gas and environmental properties by a two way analysis of variance (ANOVA), with LSD post hoc analysis where appropriate. Data from the break of season rains Experiment 2 were normally distributed, except for $\mathrm{CH}_{4}$ diffusivity, which was LN transformed to normalise distribution. The effect of water treatment was investigated using ANOVA to compare diffusivity and fluxes of $\mathrm{CH}_{4}$ and $\mathrm{N}_{2} \mathrm{O}$. The effect 
of land use was investigated using ANOVA to compare diffusivity and fluxes of $\mathrm{CH}_{4}$ and $\mathrm{N}_{2} \mathrm{O}$, for each water treatment. Seasonal mean fluxes (mass $\mathrm{CO}_{2} / \mathrm{CH}_{4} / \mathrm{N}_{2} \mathrm{Oha}^{-1} \mathrm{~d}^{-1}$ ) were estimated from the chamber data for savanna, young pasture and old pasture soils. Seasonal mean flux were multiplied by the days in each season and summed to provide an estimate of annual $\mathrm{CO}_{2}, \mathrm{CH}_{4}$ and $\mathrm{N}_{2} \mathrm{O}$ flux for each land use. Annual flux, expressed as $\mathrm{CO}_{2}$ equivalents, was estimated for each GHG based on global warming potentials (GWP) of 1 $\left(\mathrm{CO}_{2}\right), 25\left(\mathrm{CH}_{4}\right)$ and $296\left(\mathrm{~N}_{2} \mathrm{O}\right)$.

\section{Results}

\subsection{Site properties}

The properties of the nine sites are described in Table 1. All sites were located on the same soil type, red kandosols, Blain sub-order (after Lucas et al., 1985). The soils are slightly acidic, with very low levels of soil organic C ( 0.5 to $0.9 \%$ ) and total $\mathrm{N}(0.02$ to $0.06 \%)$. The pasture soils, particularly the old pastures, tended to have higher levels of $\mathrm{C}$ and $\mathrm{N}$, higher CEC and lower soil $\mathrm{pH}$ than the savanna soils (Table 1), although phosphorous levels were elevated in the pastures when compared to the savanna sites, reflecting the fertilisation of some of the pasture sites.

\subsection{Variation in soil gas fluxes with season and land use}

Over a complete wet-dry seasonal cycle at the savanna sites, higher (or less negative) fluxes of all three gas species were recorded when the soil water content was above $\sim 0.10 \mathrm{~cm}^{3} \mathrm{~cm}^{-3}$ (Fig. 2). Mean $\mathrm{CO}_{2}$ emissions ranged from 44 to $390 \mathrm{mg} \mathrm{C} \mathrm{m}^{-2} \mathrm{~h}^{-1}$, with the highest fluxes occurring during the early wet season (March). Mean $\mathrm{CH}_{4}$ uptake ranged from -24 to $-7 \mu \mathrm{g} \mathrm{m}^{-2} \mathrm{~h}^{-1}$, while mean $\mathrm{N}_{2} \mathrm{O}$ fluxes ranged from -1.0 to $1.5 \mu \mathrm{g} \mathrm{m}^{-2} \mathrm{~h}^{-1}$ over the seasonal cycle. The seasonal patterns of fluxes observed at the young pasture sites were similar to those at the savanna sites. However, the range of values recorded was greater at the young pasture sites: mean fluxes of $\mathrm{CO}_{2}$ ranged between 32 to $560 \mathrm{mg} \mathrm{C} \mathrm{m}^{-2} \mathrm{~h}^{-1} ; \mathrm{CH}_{4}-18$ to $-5 \mu \mathrm{g} \mathrm{Cm}^{-2} \mathrm{~h}^{-1}$, $\mathrm{N}_{2} \mathrm{O}-0.3$ to $1.8 \mu \mathrm{g} \mathrm{N} \mathrm{m}^{-2} \mathrm{~h}^{-1}$. Fluxes of $\mathrm{CH}_{4}$ and $\mathrm{N}_{2} \mathrm{O}$ recorded at the old pasture sites were an order of magnitude greater than fluxes measured at the other sites with peak fluxes during February when the soil water content was $\sim 0.3 \mathrm{~cm}^{3} \mathrm{~cm}^{-3}$. Over the seasonal cycle, mean $\mathrm{CH}_{4}$ fluxes ranged from -14 to $+116 \mu \mathrm{g} \mathrm{m}^{-2} \mathrm{~h}^{-1}$, and mean $\mathrm{N}_{2} \mathrm{O}$ fluxes ranged from -0.7 to $+6 \mu \mathrm{g} \mathrm{N} \mathrm{m}^{-2} \mathrm{~h}^{-1}$. Mean $\mathrm{CO}_{2}$ emissions were comparable with those at the savanna and young pasture sites.

\subsection{Variation in plant available $\mathrm{N}$ across season and land use}

Seasonal patterns of plant available $\mathrm{N}$ were assessed across land uses using soil extractions of $\mathrm{NO}_{3}^{-}$and $\mathrm{NH}_{4}^{+}$and incubated resin bags. In extracts from the soil, $\mathrm{NH}_{4}^{+}$tended to be present in higher concentrations than $\mathrm{NO}_{3}^{-}$at all sites at all times of year (Fig. 2). Concentrations of both nutrients pools across season increased in the following order: savanna $<$ young pasture $<$ old pasture. The amount of nitrate and ammonia extracted from resin bags was highest in the old pasture sites, followed by the young pasture sites and lowest in the savanna sites (Fig. 3). The highest values at all sites were recorded in the wet season, November 2007 and January 2008. Land use and seasonality both had a statistically significant effect upon soil-extracted $\mathrm{NH}_{4}^{+}$but not upon soil-extracted $\mathrm{NO}_{3}^{-}$(Table 2).

\subsection{Break of season rains: the response of trace gas fluxes}

The irrigation event, which simulated break-of-season rains, affected the fluxes of both $\mathrm{CH}_{4}$ and $\mathrm{N}_{2} \mathrm{O}$ (Fig. 4). Under the low soil moisture conditions of the late dry season (September) and prior to the wetting event, $\mathrm{N}_{2} \mathrm{O}$ at both land use sites fluctuated around $0 \mu \mathrm{g} \mathrm{N} \mathrm{m}^{-2} \mathrm{~h}^{-1}$. Following the irrigation event of $40 \mathrm{~mm}$ equivalent rainfall, fluxes increased from $\sim 0 \mu \mathrm{g} \mathrm{N} \mathrm{m}{ }^{-2} \mathrm{~h}^{-1}$ to a maximum of $19 \mu \mathrm{g} \mathrm{N} \mathrm{m} \mathrm{h}^{-2}$ in the pasture site the day after irrigation. Emissions after irrigation of the savanna soil were more moderate, reaching a maximum of $8.3 \mu \mathrm{g} \mathrm{N} \mathrm{m}^{-2} \mathrm{~h}^{-1}$ immediately after the event. Only four days after irrigation, $\mathrm{N}_{2} \mathrm{O}$ fluxes had returned to their pre-irrigation levels at both sites. This occurred despite soil water content remaining well above the initial dry soil moisture values $>5$ days after irrigation (Fig. 4 ).

Both the pasture soil $\left(-5.8 \pm 0.2 \mu \mathrm{g} \mathrm{Cm}^{-2} \mathrm{~h}^{-1}\right)$ and the savanna soil $\left(-7.8 \pm 0.3 \mu \mathrm{g} \mathrm{m}^{-2} \mathrm{~h}^{-1}\right)$ were sinks for $\mathrm{CH}_{4}$ under dry soil conditions. After the irrigation event, both soils became much weaker sinks (pasture average $-1.1 \pm 0.4 \mu \mathrm{g} \mathrm{m}^{-} 2 \mathrm{~h}^{-1}$, savanna average $-2.3 \pm 0.3 \mu \mathrm{g} \mathrm{C} \mathrm{m}{ }^{-2} \mathrm{~h}^{-1}$ ) and for short periods, sources of $\mathrm{CH}_{4}$ (maximum values of $2.2 \mu \mathrm{g} \mathrm{m}^{-2} \mathrm{~h}^{-1}$ pasture, $1.1 \mu \mathrm{g} \mathrm{C} \mathrm{m}{ }^{-2} \mathrm{~h}^{-1}$ savanna). Unlike $\mathrm{N}_{2} \mathrm{O}$ fluxes, which quickly returned to pre-irrigation values, $\mathrm{CH}_{4}$ fluxes remained at their new "wet soil" values for the duration of the experiment (i.e. greater than 5 days post irrigation).

\subsection{Break of season rains: diffusivity and soil water content}

Gas diffusivity decreased as water content increased in all three land uses (Fig. 5). Fluxes of $\mathrm{CH}_{4}$ were negative under dry soil conditions at all land uses, and became positive as the soil was wetted up (Fig. 5). Fluxes of $\mathrm{N}_{2} \mathrm{O}$ also generally 


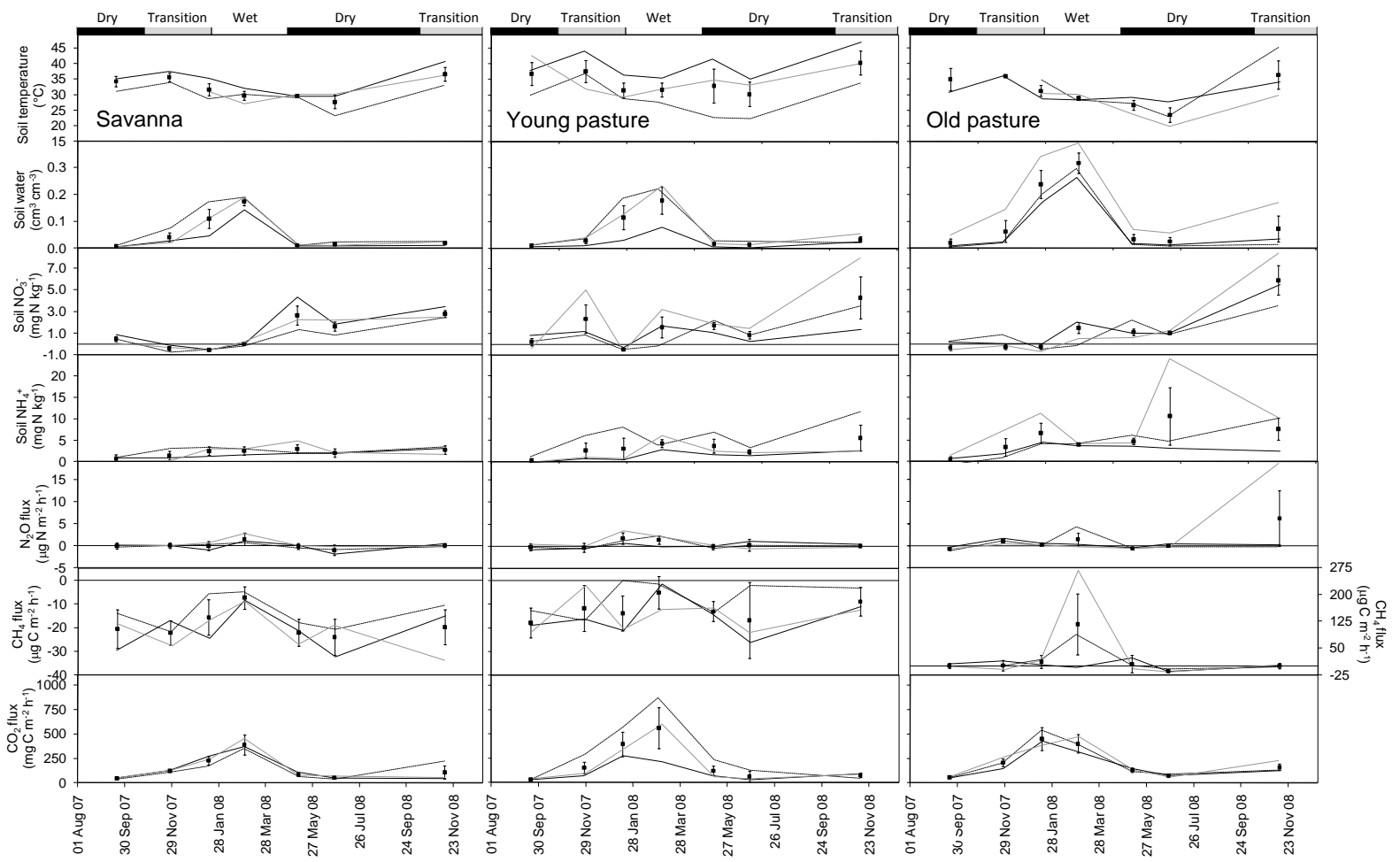

Fig. 2. Seasonal patterns of soil gas fluxes and environmental properties at savanna woodland, young pasture and old pasture sites as measured by static manual chambers on seven separate measurement events. Solid data points with standard error bars are the average of three replicate sites, as indicated by solid line, grey line and dashed line. Five measurements of flux and soil properties were made at each site.

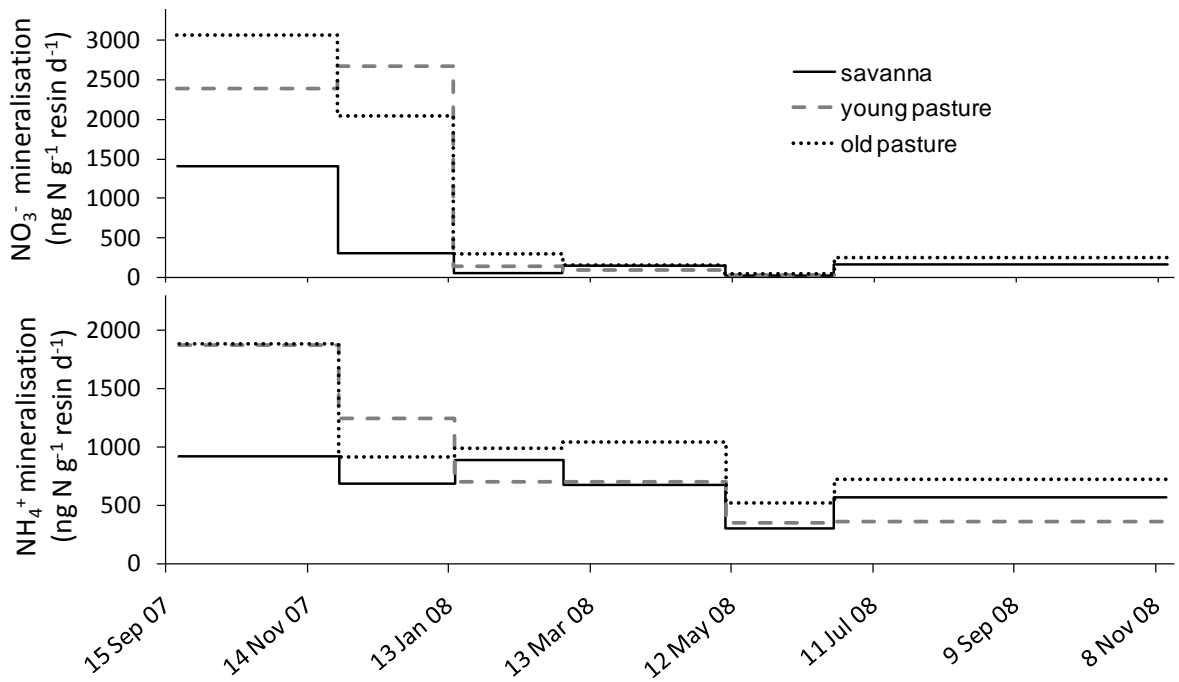

Fig. 3. Net nitrate and ammonia mineralisation rates as measured with shallow buried $(\sim 5 \mathrm{~cm})$ resin bags in savanna woodland, young pasture and old pasture sites. Means are from three replicate sites for each land use. At each site three resin bags were buried.

increased with increasing water content. Land use also had a significant effect on gas diffusivity and $\mathrm{CH}_{4}$ and $\mathrm{N}_{2} \mathrm{O}$ flux with an interaction with different soil water conditions (Table 3). Under dry conditions, land use had a significant effect upon $\mathrm{CH}_{4}$ flux, with savanna having the largest rate (net sink) when compared to the pastures. When the soil was wettest, land use significantly affected only $\mathrm{N}_{2} \mathrm{O}$ flux, with rates at the old pasture site reaching $25 \mathrm{ug} \mathrm{N} \mathrm{m}{ }^{-2} \mathrm{~h}^{-1}$ compared to less 
Table 2. The effect of land use and seasonality on soil gas fluxes and environmental properties, as determined by 2-way ANOVA with LSD post-hoc analysis. Values followed by different letters are significantly different from one another. Non-normally distributed data were transformed as indicated.

\begin{tabular}{|c|c|c|c|c|c|c|c|c|c|}
\hline & & Savanna & $\begin{array}{c}\text { Land Use } \\
\text { Young Pasture }\end{array}$ & Old Pasture & & Dry & $\begin{array}{c}\text { Season } \\
\text { Dry-wet transition }\end{array}$ & Wet & $\begin{array}{r}\text { Interaction } \\
\text { Season } \times \text { LU }\end{array}$ \\
\hline & $P$ value & Mean (se) & Mean (se) & Mean (se) & $P$ value & Mean (se) & Mean (se) & Mean (se) & $P$ value \\
\hline $\mathrm{LN} \mathrm{CO}_{2}$ & 0.000 & $4.74(0.55) \mathrm{a}$ & $4.81(0.56) \mathrm{a}$ & $5.15(0.55) b$ & 0.000 & $4.09(0.48) \mathrm{a}$ & $4.75(0.59) \mathrm{b}$ & $5.86(0.59) \mathrm{c}$ & 0.013 \\
\hline $\mathrm{LN} \mathrm{N}_{2} \mathrm{O}+10$ & 0.009 & $0.83(0.01) \mathrm{a}$ & $0.86(0.01) b$ & $0.83(0.01) \mathrm{a}$ & n.s. & $0.84(0.01)$ & $0.83(0.01)$ & $0.84(0.01)$ & n.s. \\
\hline $\mathrm{LN} \mathrm{LN} \mathrm{CH}_{4}+100$ & 0.040 & $1.50(0.01) \mathrm{a}$ & $1.53(0.01) b$ & $1.49(0.01) \mathrm{a}$ & 0.040 & $1.51(0.01) \mathrm{a}$ & $1.49(0.01) b$ & $1.51(0.01) \mathrm{ab}$ & n.s. \\
\hline Temperature & 0.000 & $32.4(0.51) \mathrm{a}$ & $34.6(0.49) \mathrm{b}$ & $31.6(0.54) \mathrm{a}$ & 0.000 & $30.7(0.43) \mathrm{a}$ & $37.1(0.58) b$ & $30.7(0.52) \mathrm{a}$ & n.s. \\
\hline LN Soil Water & 0.000 & $-3.53(0.07) \mathrm{a}$ & $-3.47(0.07) \mathrm{a}$ & $-2.88(0.07) b$ & 0.000 & $-4.48(0.06) \mathrm{a}$ & $-3.55(0.08) b$ & $-1.85(0.08) \mathrm{c}$ & n.s. \\
\hline $\mathrm{LN} \mathrm{NO}_{3}+5$ & n.s. & $1.77(0.04)$ & $1.70(0.04)$ & $1.81(0.04)$ & n.s. & $1.77(0.04)$ & $1.75(0.05)$ & $1.77(0.04)$ & n.s. \\
\hline $\mathrm{LN} \mathrm{NH}_{4}+5$ & 0.001 & $1.98(0.05) \mathrm{a}$ & $2.18(0.05) b$ & $2.22(0.05) b$ & 0.007 & $2.09(0.04) \mathrm{a}$ & $2.26(0.06) b$ & $2.02(0.04) \mathrm{a}$ & n.s. \\
\hline LN BD & 0.000 & $0.33(0.01) \mathrm{a}$ & $0.41(0.01) b$ & $0.42(0.01) b$ & & & & & n.s. \\
\hline
\end{tabular}

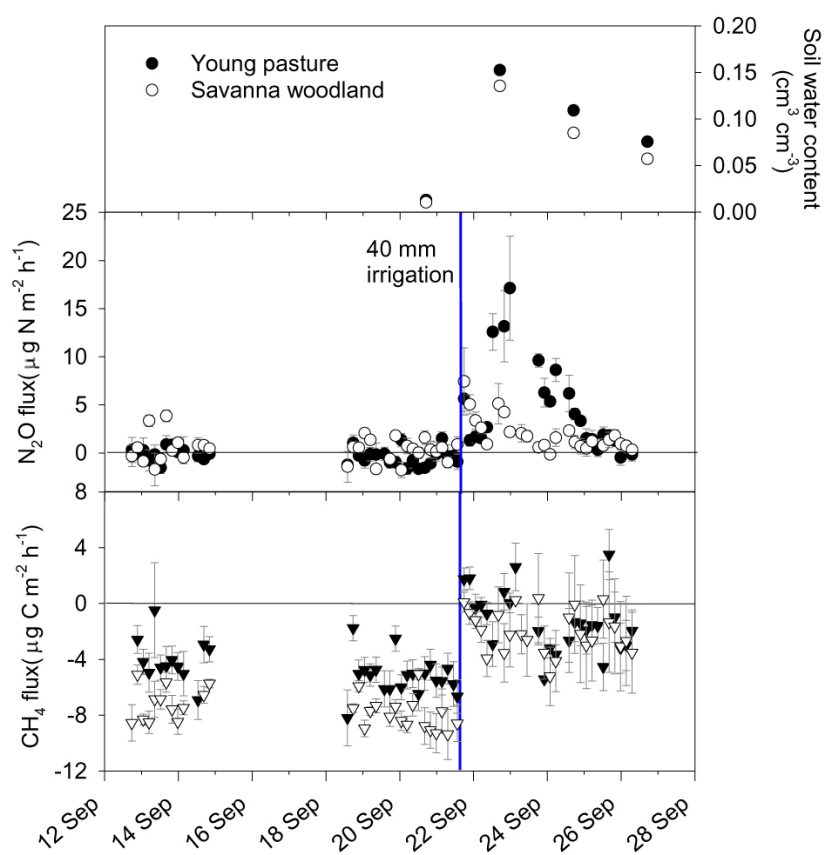

Fig. 4. Methane and nitrous oxide fluxes from soil in a savanna woodland (open symbols) and adjacent young pasture (closed symbols), before and after a $40 \mathrm{~mm}$ irrigation event. Error bars are the standard errors from five replicate chambers. Soil water content was measured before and during the irrigation experiment (young pasture closed circles, savanna open circles).

than $5 \mathrm{ug} \mathrm{N} \mathrm{m}{ }^{-2} \mathrm{~h}^{-1}$ at the savanna (Fig. 5). Under medium soil wetness, land use significantly affected diffusivity and $\mathrm{N}_{2} \mathrm{O}$.

\subsection{Relationships between gas fluxes and environmental drivers}

Given the large seasonality in fluxes as described above, analysis of land use change was undertaken within each seasonal period, namely wet, dry and dry-wet season transition. Statistical analysis of fluxes for each season and land use is given in Table 2. Land use had a statistically significant effect upon the fluxes of all three gases and upon soil temperature, soil water content and bulk density (Table 2). Seasonality had a statistically significant effect upon $\mathrm{CO}_{2}$, $\mathrm{CH}_{4}$, soil temperature and soil water content and the interaction between land use and seasonality was only significant for $\mathrm{CO}_{2}$ (Table 2). Relationships between soil fluxes and environmental drivers (soil water content, soil temperature, soil $\mathrm{NO}_{3}^{-}$and $\mathrm{NH}_{4}^{+}$, available $\mathrm{NO}_{3}^{-}$and $\mathrm{NH}_{4}^{+}$) were investigated across all land use sites and seasons using step-wise multiple regression. For all gases and all land uses, stepwise multiple regression yielded only one significant driving factor $(p<0.01)$ and for most treatment combinations this was soil water content. The exceptions were: soil $\mathrm{NH}_{4}^{+}$was the significant driving factor affecting $\mathrm{CH}_{4}$ fluxes in the young pasture, and soil $\mathrm{NO}_{3}^{-}$was the significant driving factor affecting $\mathrm{N}_{2} \mathrm{O}$ fluxes in the old pasture. The ability of these regression relationships to describe the variation in gas fluxes (as quantified by $r^{2}$ ) ranged from 0.29 to 0.69 . The relationship between gas flux and soil moisture was strongest at the savanna site and is given in Fig. 6. Over the observed range of soil moisture, $\mathrm{N}_{2} \mathrm{O}$ flux was negative (net uptake by the soil) until a threshold moisture content of $0.06 \mathrm{~m}^{3} \mathrm{~m}^{-3}$ was reached. Moisture levels above this value resulted in emission, with a maximal rate of $5 \mathrm{ug} \mathrm{N} \mathrm{m}^{-2} \mathrm{~h}^{-1}$ at $\sim 0.2 \mathrm{~m}^{3} \mathrm{~m}^{-3}$ soil water content (Fig. 6). Methane and $\mathrm{CO}_{2}$ fluxes were both positively related to soil water content, with moisture content alone explaining $70 \%$ of the observed variation in soil $\mathrm{CO}_{2}$ efflux.

\subsection{Cumulative flux estimates}

Fluxes of $\mathrm{N}_{2} \mathrm{O}$ were positive for all land uses in the wet season and the dry-wet transition, but in the dry season, there was a net uptake of $\mathrm{N}_{2} \mathrm{O}$ by the soil in the savanna and the old pasture sites (Table 4). Methane was absorbed by the soil all 
Table 3. The effect of water content and land use on gas diffusivity, $\mathrm{CH}_{4}$ and $\mathrm{N}_{2} \mathrm{O}$ fluxes, as determined by ANOVA. Diffusivity data were $\mathrm{LN}$ transformed to improve the normality of their distribution. The $p$-value is reported for significant results, non-significant results are indicated by n.s., and post hoc tests (Tukey's) were used to determine how the three water contents differed. Different letters indicate where results were significantly different from one another.

\begin{tabular}{|c|c|c|c|c|}
\hline & & Dry & Medium & We \\
\hline$p$-value & \multicolumn{4}{|c|}{ Effect of water content pooled across all land uses } \\
\hline Diffusivity & 0.001 & $\mathrm{a}$ & $\mathrm{b}$ & $\mathrm{b}$ \\
\hline $\mathrm{CH}_{4}$ & 0.006 & a & $\mathrm{b}$ & $\mathrm{ab}$ \\
\hline $\mathrm{N}_{2} \mathrm{O}$ & 0.02 & $\mathrm{a}$ & $\mathrm{b}$ & $\mathrm{ab}$ \\
\hline \multicolumn{5}{|c|}{ Effect of land use } \\
\hline Diffusivity & & n.s. & 0.002 & n.s \\
\hline $\mathrm{CH}_{4}$ & & 0.000 & n.s. & n.s \\
\hline $\mathrm{N}_{2} \mathrm{O}$ & & n.s. & 0.004 & 0.008 \\
\hline
\end{tabular}

year in the savanna and the young pasture, but $\mathrm{CH}_{4}$ was emitted from the old pasture in the dry-wet transition and in the wet season. Comparison of seasonal fluxes demonstrated that the wet season was when the largest positive rates occurred, i.e. net emission of GHG. This held true across all land uses and all gases. The annual fluxes indicate that the conversion from savanna to pasture has increased greenhouse gas emissions from the soil by $17.36 \mathrm{tCO}_{2}$-equivalent ha $\mathrm{ha}^{-1} \mathrm{y}^{-1}$, and decreased the ability of the soil to act as a sink for $\mathrm{CH}_{4}$ (Table 4). When all gas fluxes are converted to $\mathrm{CO}_{2}$ equivalent units, $\mathrm{CO}_{2}$ was the dominant flux from these land use types, despite the greater warming potentials of $\mathrm{CH}_{4}$ and $\mathrm{N}_{2} \mathrm{O}$.

\section{Discussion}

This study focused on quantifying fluxes of $\mathrm{CH}_{4}, \mathrm{~N}_{2} \mathrm{O}$ and $\mathrm{CO}_{2}$ from soils of contrasting land use types in the DouglasDaly River basin in the NT. This region has been identified as a catchment for potential intensification of horticulture, plantation forestry and cattle grazing. Soil types sampled in this study are from the Blain and Oolloo sub-orders (Lucas et al., 1985) of the red kandosol group and are the soil types targeted for agricultural development, occupying $>200000$ ha within the catchment. Understanding of greenhouse gas emissions associated with differing land use decision making is now essential for national greenhouse gas inventory reporting (Cook et al., 2010). The Carbon Farming Initiative (www.daff.gov.au/climatechange/cfi) is a recent policy development in Australia aimed at reducing national GHG emissions via modified land management practises. Land managers can trade carbon credits based on changes in land use practices that store more carbon or reduce emissions relative to a baseline. As part of this trading scheme, eligi- ble emission avoidance projects can include soil based $\mathrm{CO}_{2}$ and non- $\mathrm{CO}_{2}$ fluxes. Also countable are carbon sequestration projects that enhance sequestration in soils or biomass or avoid emissions.

Essential for the effective assessment of projects under this scheme is an understanding of the likely impacts on emissions that may, or may not arise for a given change in management. Models such as DNDC could play a role in assessments and even verification of emissions at property or even regional scales. For such schemes to be credible, it is essential that data are available that provide estimates of baseline fluxes for a given land use and for the calibration of process models. This study is the first comprehensive work in Northern Australia to investigate the effect of savanna clearing and the establishment of improved pastures on soil based greenhouse gas fluxes. Our results clearly show that conversion of savanna ecosystems to grazed pastures increases the overall greenhouse gas flux to the atmosphere, with increases in $\mathrm{CO}_{2}$ and $\mathrm{N}_{2} \mathrm{O}$ fluxes and decreases in soil $\mathrm{CH}_{4}$ uptake (Table 4).

\subsection{Effect of land use change on $\mathrm{N}_{2} \mathrm{O}$ flux}

Emissions of $\mathrm{N}_{2} \mathrm{O}$ were near zero across all sites and seasons, although there was evidence of a spike in $\mathrm{N}_{2} \mathrm{O}$ emissions of up to $20 \mu \mathrm{N} \mathrm{m}^{-2} \mathrm{~h}^{-1}$ following break of season rainfall. While this was a maximal rate observed during this measurement program, when compared with other savanna ecosystems, these $\mathrm{N}_{2} \mathrm{O}$ fluxes are well below the global average emissions for natural savannas (Dalal and Allen, 2008). $\mathrm{N}_{2} \mathrm{O}$ fluxes from pasture and both primary and secondary wet forest in subtropical Puerto Rico were of a similarly low magnitude as in our study (below $2 \mu \mathrm{g} \mathrm{N} \mathrm{m}^{-2} \mathrm{~h}^{-1}$ ), except where the forest was fertilized or dominated by leguminous $\mathrm{N}$ fixing species (Erickson et al., 2001). The low $\mathrm{N}_{2} \mathrm{O}$ fluxes observed in our study are likely due to the low $\mathrm{N}$ content of the soils $(0.02-0.07 \% \mathrm{~N})$. In such a low $\mathrm{N}$ system, $\mathrm{N}$ is tightly cycled and this is reflected in the low levels of soil nitrate and ammonia (Fig. 2), as was also found for a pine forest in the Mediterranean region (Rosenkranz et al., 2006). Dry conditions and low atmospheric $\mathrm{N}$ deposition also play a role in situations with low $\mathrm{N}_{2} \mathrm{O}$ fluxes (Dalal and Allen, 2008). The negative $\mathrm{N}_{2} \mathrm{O}$ fluxes (net soil uptake) observed were all associated with dry soil conditions and likely occur in low $\mathrm{N}$ systems when sufficient air can diffuse through soil pores to allow $\mathrm{N}$-starved microbes to use gaseous $\mathrm{N}_{2} \mathrm{O}$ as an $\mathrm{N}$ source (Rosenkranz et al., 2006). $\mathrm{N}_{2} \mathrm{O}$ uptake has been observed in savanna soils in West Africa, in dry tropical forest soils in Puerto Rico and in sandy soils stocked with Pine in the Mediterranean region (Brümmer et al., 2008; Erickson et al., 2002; Rosenkranz et al., 2006). However, the processes involved are, as yet, poorly understood (Dalal and Allen, 2008).

The $\mathrm{N}_{2} \mathrm{O}$ emissions recorded in the old pasture occurred at the end of the dry season, with the first rain of the dry-wet 

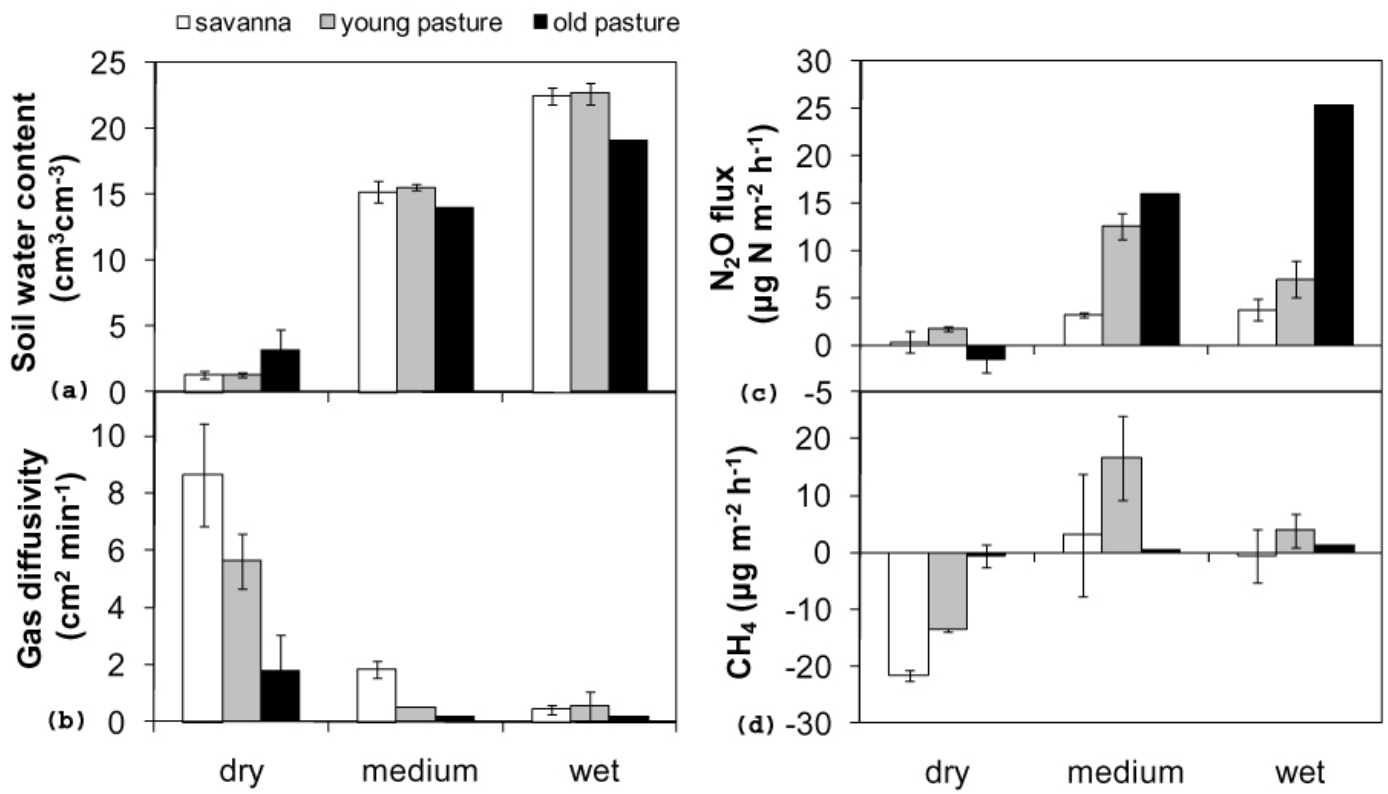

Fig. 5. The effect of artificially increased soil water contents (a) upon soil gas diffusivity (b) and soil $\mathrm{CH}_{4}(\mathbf{c})$ and $\mathrm{N}_{2} \mathrm{O}$ (d) fluxes. White bars are savanna woodland, grey bars are young pasture and black bars are old pasture. Standard error bars $(n \leq 3)$ are indicated.

Table 4. Seasonal and annual cumulative fluxes of $\mathrm{CO}_{2}, \mathrm{~N}_{2} \mathrm{O}$ and $\mathrm{CH}_{4}$ for each land use, calculated from manual chamber flux data. Note that $\mathrm{CO}_{2}$ is in tonnes $\left(\mathrm{tCO}_{2}-\mathrm{Cha}^{-1} \mathrm{y}^{-1}\right)$ while $\mathrm{N}_{2} \mathrm{O}$ and $\mathrm{CH}_{4}$ are in kilograms $\left(\mathrm{kg} \mathrm{N}_{2} \mathrm{O}-\mathrm{Nha}^{-1} \mathrm{y}^{-1}, \mathrm{~kg} \mathrm{CH}_{4}-\mathrm{Cha}^{-1} \mathrm{y}^{-1}\right)$. The final row is in $\mathrm{CO}_{2}$-equivalent units $\left(\mathrm{tha}^{-1} \mathrm{y}^{-1}\right)$.

\begin{tabular}{|c|c|c|c|c|c|c|c|c|c|}
\hline \multirow[b]{2}{*}{ Season } & \multicolumn{3}{|c|}{$\mathrm{CO}_{2}$} & \multicolumn{3}{|c|}{$\mathrm{N}_{2} \mathrm{O}$} & \multicolumn{3}{|c|}{$\mathrm{CH}_{4}$} \\
\hline & Savanna & Young pasture & Old pasture & Savanna & Young pasture & Old pasture & Savanna & Young pasture & Old pasture \\
\hline Dry-wet transition & 3.34 & 4.53 & 5.95 & 0.00 & 0.01 & 0.06 & -0.42 & -0.25 & 0.09 \\
\hline Wet & 8.54 & 12.28 & 8.76 & 0.03 & 0.03 & 0.03 & -0.16 & -0.11 & 2.55 \\
\hline Dry & 2.66 & 3.15 & 3.79 & -0.02 & 0.00 & -0.02 & -0.97 & -0.70 & -0.12 \\
\hline Annual sums & 14.55 & 19.96 & 18.50 & 0.02 & 0.05 & 0.07 & -1.55 & -1.06 & 2.52 \\
\hline Annual $\mathrm{CO}_{2}$-e & 53.35 & 73.19 & 67.84 & 0.01 & 0.02 & 0.03 & -0.05 & -0.03 & 0.08 \\
\hline
\end{tabular}

transition. Our manual chamber results show some evidence of a build up of soil nitrate and ammonia during the dry season, with a small pulse of $\mathrm{N}_{2} \mathrm{O}$ emission with the first rain of the dry-wet transition. This phenomenon is more clearly demonstrated in the break of season rains, Experiment 1. $\mathrm{N}_{2} \mathrm{O}$ emissions are often a result of denitrification and increase as the soil becomes wetter (Dalal and Allen, 2008). However, when the soil was wettest in our study there was little soil nitrate or ammonia present and thus $\mathrm{N}_{2} \mathrm{O}$ fluxes remained low.

The land use change in our study was from native savanna vegetation to grazed pasture, and this increased $\mathrm{N}_{2} \mathrm{O}$ flux from the soil. Compaction by grazing can increase bulk density in pasture soils (as seen in Table 2), decreasing pore space and limiting gas diffusion. Gas diffusivity was lowest in the old pasture and highest in the savanna under all water treatments, in the break of season rains Experiment 2. Trop- ical forest soils converted to pasture initially emitted more $\mathrm{N}_{2} \mathrm{O}$ than the forest soils, but from 10 to $35 \mathrm{yr} \mathrm{N}_{2} \mathrm{O}$ fluxes decreased as pasture age increased, to values $1 / 2$ to $1 / 3$ lower than the original forest soil emissions (Keller et al., 1993). In dry tropical forest in Puerto Rico, an increase in leguminous $\mathrm{N}_{2}$ fixing tree species brought about by prior agricultural use lead to greater $\mathrm{N}_{2} \mathrm{O}$ fluxes from the post-agricultural forest than from old forest sites (Erickson et al., 2002). Land use change from native vegetation to cropping decreased $\mathrm{N}_{2} \mathrm{O}$ flux from savanna soils in West Africa and also from semiarid Mallee soils in Southeastern Australia (Brümmer et al., 2008; Galbally et al., 2010). Cropping may increase gas diffusion through the soil as soil structure is opened up by tillage. The effect of land use change on soil structure and $\mathrm{N}$ cycling will influence the outcome of this change on soil $\mathrm{N}_{2} \mathrm{O}$ fluxes. 


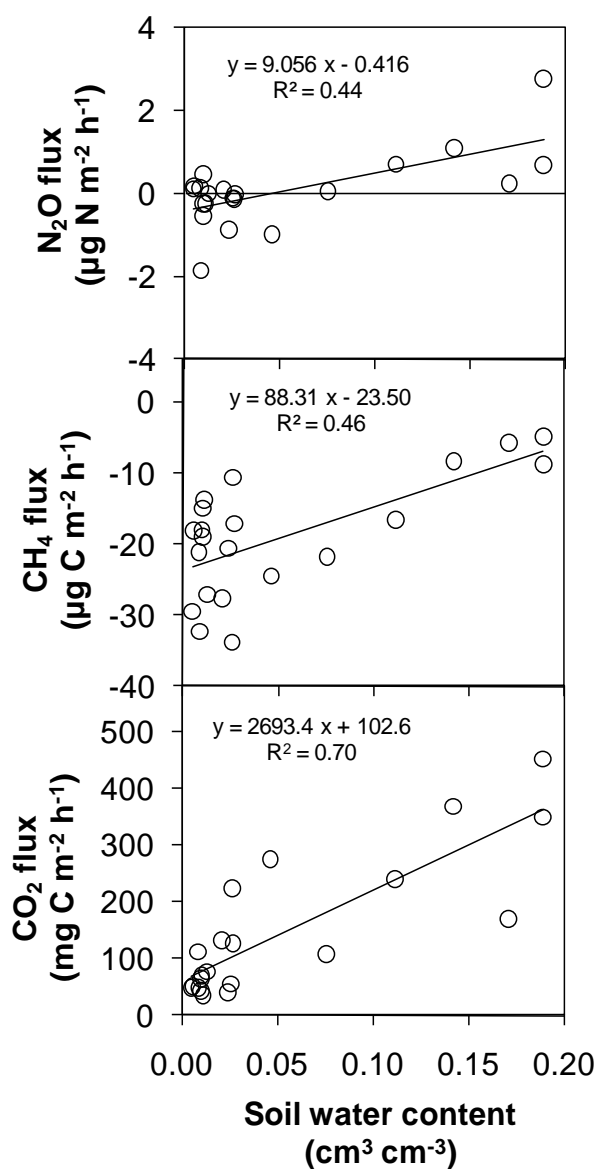

Fig. 6. The relationships between soil water content and $\mathrm{CO}_{2}$, $\mathrm{CH}_{4}$ and $\mathrm{N}_{2} \mathrm{O}$ fluxes from savanna soils in the Douglas Daly region. Each point is the average value from five replicate chambers as measured at woodland, young pasture and old pasture sites on seven occasions through a 14 month period.

\subsection{Seasonal changes in $\mathrm{N}_{2} \mathrm{O}$ flux}

We could not detect a seasonal pattern of $\mathrm{N}_{2} \mathrm{O}$ fluxes, which were generally very low in all ecosystems and did not change significantly with changes in the environmental conditions. The only exception were the break of season rains, that resulted in sizable (though still small in comparison with other ecosystems) emissions of $\mathrm{N}_{2} \mathrm{O}\left(15-25 \mu \mathrm{g} \mathrm{N} \mathrm{m}{ }^{-2} \mathrm{~h}^{-1}\right)$ the day after the irrigation. This effect, however, was transient and four days after the break of season rains experiment, the soil was still wet but $\mathrm{N}_{2} \mathrm{O}$ emissions had returned to near zero (Fig. 3). Brümmer et al. (2008) also observed a pulse of $\mathrm{N}_{2} \mathrm{O}$ when the first rains fell after the dry season, in savanna in Burkina Faso, West Africa. Ongoing wet soil conditions did not yield continuing high $\mathrm{N}_{2} \mathrm{O}$ fluxes, likely because the soil nitrate and ammonia that built up in the dry season had been used up.

This lack of seasonality was also observed in other studies, such as a near-continuous 16 month study of $\mathrm{N}_{2} \mathrm{O}$ fluxes from savanna soils at Howard Springs in Northern Australia (Livesley et al., 2011) or in $\mathrm{N}_{2} \mathrm{O}$ fluxes from pasture or forest soils in tropical Puerto Rico (Erickson et al., 2001). The most likely explanation for the lack of seasonality is the low nitrogen levels of the system. Even when soil was near field capacity, i.e. favourable for denitrification and production of $\mathrm{N}_{2} \mathrm{O}$, all the $\mathrm{N}$ present is efficiently immobilized by plants and soil microbes. The sand fraction of the top $50 \mathrm{~cm}$ depth in these soils tends to range from 80 to $90 \%$, which may prevent the formation of anaerobic microsites where denitrification would take place. In times when mineralisation and nitrification occurs (i.e. in the transition period between wet and dry, Fig. 5) most of the available $\mathrm{NO}_{3}^{-}$is probably taken up by plants or immobilised by microbes and not lost as $\mathrm{N}_{2} \mathrm{O}$ via nitrification.

\subsection{Effect of land use change upon $\mathrm{CH}_{4}$ flux}

Conversion of savanna woodland to pasture decreased the $\mathrm{CH}_{4}$ sink strength of the soils. Under the environmental conditions encountered during the manual chamber measurements, the young pasture soils remained weak sinks for $\mathrm{CH}_{4}$, while the old pastures became substantial sources of $\mathrm{CH}_{4}$ under wet conditions. This is consistent with a review of global patterns of $\mathrm{CH}_{4}$ flux from natural and managed savannas by Castaldi et al. (2006), which found that land use change dramatically decreased the $\mathrm{CH}_{4}$ sink strength of soils, and conversion to pasture resulted in the soil becoming a $\mathrm{CH}_{4}$ source in the wet season (Castaldi et al., 2006). The magnitude of fluxes that we measured is within the standard deviation of the global mean value as given by Castaldi et al. (2006) for savanna and seasonally dry ecosystems (annual daily mean $-0.48 \pm 0.96 \mathrm{mg} \mathrm{CH}_{4} \mathrm{~m}^{-2} \mathrm{~d}^{-1}$ ). In the break of season rains experiments, conducted under wetter conditions than were encountered in the manual chamber measurements, both the young pasture and the old pasture became net sources of $\mathrm{CH}_{4}$. Methane is produced under anaerobic conditions by methanogenic bacteria. When soil is aerobic, $\mathrm{CH}_{4}$ is consumed by methanotrophic bacteria (Dalal and Allen, 2008) and the change from $\mathrm{CH}_{4}$ sink to $\mathrm{CH}_{4}$ source observed with conversion to pasture is likely to be related to the increase in bulk density associated with grazing. Compaction by grazing animals decreases the pore space in soils, thus the volumetric water content in pasture soils will be higher for a given rain fall than in adjacent savanna woodland soils. This can be seen in the soil water content data from the break of season rains Experiment 1 . Consequently anaerobic microsites, being locations of net $\mathrm{CH}_{4}$ production, will be more prevalent in pasture soils compared to natural savanna soils.

Land use change from native vegetation to pasture has decreased the $\mathrm{CH}_{4}$ sink strength of soils in a variety of ecosystems. Conversion of tropical forest to pasture decreased $\mathrm{CH}_{4}$ consumption by soils in the dry season, and altered the system from a $\mathrm{CH}_{4}$ sink to a $\mathrm{CH}_{4}$ source in the wet season. Pasture age did not affect $\mathrm{CH}_{4}$ fluxes (Keller et al., 1993). 
Land use change from native forest to pasture decreased the $\mathrm{CH}_{4}$ sink strength of soils in south west Western Australia (Livesley et al., 2009). In contrast, reafforestation of the pasture with Pinus radiata and Eucalyptus globulus improved the ability of the soils to remove $\mathrm{CH}_{4}$ from the atmosphere but not back to the levels of the original forest (Livesley et al., 2009). In contrast, when native vegetation is replaced by cropping, the $\mathrm{CH}_{4}$ sink strength of the soil can increase, likely because cultivation can decrease bulk density and increase the air-filled porosity of the soil and thus the soil gas diffusivity. In contrast to this study, Brümmer et al. (2009) found that savanna soils converted to cropping were stronger sinks of $\mathrm{CH}_{4}$ when compared to native savanna soils. Galbally et al. (2010) also found that soils converted to wheat cropping were a stronger sink for $\mathrm{CH}_{4}$ than the native mallee vegetation in semiarid Southeastern Australia. A positive correlation between $\mathrm{CH}_{4}$ sink strength and time since cropping was abandoned and afforestation began was found in soils in Scotland and Denmark (Prieme et al., 1997). These varied results emphasise that rainfall distribution, soil type and both current and past land use and their affect upon soil structure and water holding capacity need to be considered in the management of $\mathrm{CH}_{4}$ fluxes from soils.

\subsection{Seasonal changes in $\mathrm{CH}_{4}$ flux}

Season had a statistically significant effect upon $\mathrm{CH}_{4}$ flux from the soil, due to the large seasonal differences in soil water content between seasons typical of the wet-dry tropics. During the dry season, soil water content declined to between 0.02 and $0.05 \mathrm{~cm}^{3} \mathrm{~cm}^{-3}$ and the soils were a sink for $\mathrm{CH}_{4}$ under these conditions. As soil moisture increased through the dry-wet transition and into the wet season, the soil became a weaker sink and sometimes a source of $\mathrm{CH}_{4}$ to the atmosphere. Methanotrophy is limited by gas diffusion into the soil as diffusion controls the movement of $\mathrm{CH}_{4}$ from the bulk air to the microbes in the soil. Diffusion occurs through air filled pores. Water filled pores limit gas diffusion, clearly demonstrated in the break of season rains Experiment 2. Methanogenesis occurs when soils are sufficiently waterlogged, leading to $\mathrm{O}_{2}$ depletion in the soil and prevailing anaerobiosis. This occurred at the old pasture sites under the environmental conditions encountered during the manual chamber measurements and in all soils during the break of season rains experiments. Our results concur with a synthesis of $\mathrm{CH}_{4}$ fluxes from savannas which found that there was a statistically significant difference between wet season and dry season fluxes (Castaldi et al., 2006). Brümmer et al. (2009) found that both cropped and intact savanna soils were $\mathrm{CH}_{4}$ sources when wet and $\mathrm{CH}_{4}$ sinks when dry. Dry season $\mathrm{CH}_{4}$ consumption was 2 to 3 times greater than wet season $\mathrm{CH}_{4}$ consumption in tropical forest soils in Costa Rica (Keller et al., 1993). In contrast, the $\mathrm{CH}_{4}$ fluxes at a savanna woodland in Northern Australia showed no seasonal pattern at the Howard Springs savanna flux tower site, a higher rainfall savanna site (1700 $\mathrm{mm}$ annual rainfall) near Darwin, NT (Livesley et al., 2011).

\subsection{Effect of land use change upon $\mathrm{CO}_{2}$ flux}

The change in land use from native savanna woodland to pasture increased emissions of $\mathrm{CO}_{2}$ from the soil. The highest $\mathrm{CO}_{2}$ emissions occurred in the young pasture. This may be explained by the hotter and wetter conditions in the pasture soils, which had less shading and insulation by vegetation than the savanna soils. Substrate availability likely also played a role in the higher $\mathrm{CO}_{2}$ fluxes from the pasture soils, similarly the presence of dense, fibrous grass roots beneath the soil surface and occasional grass foliage within a chamber. Table 2 indicates that the pasture soils had higher carbon contents than the savanna soils (savanna $0.56 \% \mathrm{C}$, young pasture $0.73 \% \mathrm{C}$, old pasture $0.85 \% \mathrm{C}$ ). The magnitude of $\mathrm{CO}_{2}$ fluxes in our study is similar to those of a savanna open-forest in north Australia (Livesley et al., 2011). In contrast to our results, pasture soils emitted less $\mathrm{CO}_{2}$ than primary and secondary forest soils on an annual basis in the wet dry tropics of the eastern Amazon Basin (Davidson et al., 2000). However, the highest and lowest monthly measurements were recorded at pasture sites. Brümmer et al. (2009) found that natural savanna soils produced more $\mathrm{CO}_{2}$ than cropped savanna soils. This may be because cropping tends to reduce levels of $\mathrm{C}$ in the soil due to tillage.

\subsection{Seasonal changes in $\mathrm{CO}_{2}$ flux}

Season had a significant effect upon the flux of $\mathrm{CO}_{2}$ from the soil. $\mathrm{CO}_{2}$ fluxes increased dry $<$ dry-wet transition $<$ wet. The change in $\mathrm{CO}_{2}$ flux with season has been well documented in many different ecosystems, and is generally attributed to the increase in temperature in summer (Dalal and Allen, 2008). However, in the wet dry tropics of Northern Australia, there is little change in temperature with season and we found no statistically significant effect of temperature upon $\mathrm{CO}_{2}$ efflux. Rather, it is water content that changes and our data show that water content, rather than soil temperature, drives the change in $\mathrm{CO}_{2}$ efflux with season. Other north Australia measures of soil $\mathrm{CO}_{2}$ efflux found similar seasonal dynamics with both Chen et al. (2002) and Livesley et al. (2011) reporting a five-fold seasonal difference in $\mathrm{CO}_{2}$ flux from the soil over a complete seasonal cycle at the Howard Springs flux site largely driven by soil moisture, although Chen et al. (2002) observed an interaction between soil temperature and soil water content with a relationship between $\mathrm{CO}_{2}$ efflux and soil temperature evident but only in wet soils. Davidson et al. (2000) measured soil $\mathrm{CO}_{2}$ efflux in the wet dry tropics of the eastern Amazon Basin where there is also little variation in soil temperature, in order to investigate the effect of seasonal change in soil water content. They found that soil water content, in the absence of a confounding temperature effect, had a significant effect upon 
$\mathrm{CO}_{2}$ flux. Brümmer et al. (2009) also found that soil water content, rather than soil temperature, controlled $\mathrm{CO}_{2}$ flux from savanna soils.

This research and the studies mentioned above add to a growing body of evidence which suggests that global climate models need to account for the dominant effect of soil water content on $\mathrm{CO}_{2}$ efflux in systems which experience little annual change in temperature and which are water limited for part or most of the year. Such ecosystems (seasonally dry forests, tropical, semi-arid and temperate savannas) occupy approximately $20 \%$ of the Earth land surface (Hutley and Setterfield, 2008). Chen et al. (2002) estimated that predicting soil $\mathrm{CO}_{2}$ emissions from savannas based on temperature alone would result in errors in both the seasonality and magnitude of fluxes. Soil respiration of these savannas is typically $>70 \%$ of ecosystem respiration (Chen et al., 2003) and is between 10 to $15 \mathrm{tC} \mathrm{ha}^{-1} \mathrm{y}^{-1}$ : a significant flux of $\mathrm{CO}_{2}$ to the atmosphere when extrapolated across the seasonal tropics.

\subsection{Annual budget}

Conversion of savanna woodland to pasture decreases the $\mathrm{CH}_{4}$ sink strength of the soil and may, under wet conditions, result in emissions of both $\mathrm{CH}_{4}$ and $\mathrm{N}_{2} \mathrm{O}$. Pasture soils consistently emit more $\mathrm{CO}_{2}$ than savanna soils and thus, the net effect of this land use change is an increase in greenhouse gas emissions from soil. However, the net effect on the whole ecosystem also includes the contribution of plants to $\mathrm{CO}_{2}$ uptake and $\mathrm{C}$ sequestration, and thus measurements of net ecosystem exchange are required to fully understand the greenhouse gas impacts of converting savanna to pasture. Methane production by termites was found to offset $21 \%$ of the soil $\mathrm{CH}_{4}$ sink in similar savanna types in north Australia (Jamali et al., 2011). Brümmer et al. (2009) found that converting savanna to cropping decreased the abundance of termite mounds, and thus reduced the $\mathrm{CH}_{4}$ producing potential of the ecosystem. Termites in our savanna live in mounds, in trees and below the ground, and it is not clear whether their abundance is reduced by conversion of savanna to pasture. The annual GHG emission from each land use type in $\mathrm{CO}_{2}$ equivalent units was 53.31, 73.19 and $67.95 \mathrm{tCO}_{2}-\mathrm{e} \mathrm{ha}^{-1} \mathrm{y}^{-1}$ for the savanna, young and old pasture respectively (Table 2). These estimates demonstrate that $\mathrm{CH}_{4}$ and $\mathrm{N}_{2} \mathrm{O}$ make up only a small proportion of the overall greenhouse gas flux from these systems, which is dominated by $\mathrm{CO}_{2}$. Our estimate of annual $\mathrm{CO}_{2}$ emissions from the savanna soil $\left(14.55 \mathrm{tCO}_{2}-\mathrm{Cha}^{-1} \mathrm{y}^{-1}\right)$ is in close agreement with the results from savanna woodland in a higher rainfall area of Northern Australia (Chen et al., 2002) (14.3 $\left.\mathrm{tha}^{-1} \mathrm{y}^{-1}\right)$ and (Livesley et al., 2011) $\left(13.26 \mathrm{tha}^{-1} \mathrm{y}^{-1}\right)$. Across land uses, clearing essentially increased GHG by $30 \%$, largely driven by increased soil $\mathrm{CO}_{2}$ fluxes.

\section{Conclusions}

This study clearly demonstrated that land use change from savanna to pasture increased the greenhouse gas flux from the soil. More importantly, savanna clearing led to increases in fluxes to the atmosphere of all three greenhouse gases. Nitrous oxide and $\mathrm{CO}_{2}$ fluxes increased after conversion of savannas to pastures and soil $\mathrm{CH}_{4}$ uptake decreased and some pastures became a $\mathrm{CH}_{4}$ source. Most of these changes can be explained by the structural changes of the ecosystems - pastures were exposed to greater fluctuations in soil moisture and greater soil temperature and generally showed a lower soil diffusivity. This led to greater rates of denitrification and increased nitrification and subsequent increases in $\mathrm{N}_{2} \mathrm{O}$ fluxes but also to significant decreases in $\mathrm{CH}_{4}$ uptake. The $\mathrm{CO}_{2}$ fluxes also increased as soil water content increased, and the pasture soils consistently produced more $\mathrm{CO}_{2}$ than the savanna soils. A conversion of savannas to pastures in Northern Australia means therefore that there may be an increase in greenhouse gas emissions in $\mathrm{CO}_{2}$ equivalents from the soil ecosystem and our study highlights that soil greenhouse gas exchange processes need to be considered to inform land use decision making in this least-developed part of Australia. These findings are particularly significant given the development of carbon credit trading schemes now operational and targeting emissions from agricultural and grazing systems. The greenhouse costs associated with clearing can now be factored into land use decision making with more certainty for these savanna ecosystems.

Acknowledgements. This research was funded by the Australian Research Council grant LP0774812 and partner organisations the NT Government and Department of Climate Change and Energy Efficiency, Canberra. Bianca Baldiserra, Luke Wiley and Susanna Venn assisted with field and laboratory analyses. We also thank land holders in the Daly River catchment for access to their properties for soil sampling and measurement.

Edited by: A. B. Guenther

\section{References}

Arneth, A., Sitch, S., Bondeau, A., Butterbach-Bahl, K., Foster, P., Gedney, N., de Noblet-Ducoudr, N., Prentice, I. C., Sanderson, M., Thonicke, K., Wania, R., and Zaehle, S.: From biota to chemistry and climate: towards a comprehensive description of trace gas exchange between the biosphere and atmosphere, Biogeosciences, 7, 121-149, doi:10.5194/bg-7-121-2010, 2010.

Beringer, J., Hutley, L. B., Tapper, N. J., Coutts, A., Kerley, A., and O'Grady, A. P.: Fire impacts on surface heat, moisture and carbon fluxes from a tropical savanna in Northern Australia., Int. J. Wildland Fire, 12, 1-8, 2003.

Beringer, J., Hutley, L. B., Tapper, N. J., and Cernusak, L. A.: Savanna fires and their impact on net ecosystem productivity in North Australia, Glob. Change Biol., 13, 990-1004, 2007. 
Borken, W. and Matzner, E.: Reappraisal of drying and wetting effects on $\mathrm{C}$ and $\mathrm{N}$ mineralisation and fluxes in soils, Glob. Change Biol., 15, 808-824, 2008.

Bowman, D. M. J. S., Brown, G. K., Braby, M. F., Brown, J. R., Cook, L. G., Crisp, M. D., Ford, F., Haberle, S., Hughes, J., Isagi, Y., Joseph, L., McBride, J., Nelson, G., and Ladiges, P. Y.: Biogeography of the Australian monsoon tropics, J. Biogeogr., 37, 201-216, 2010.

Breuer, L., Kiese, R., and Butterbach-Bahl, K.: Temperature and moisture effects on nitrification rates in tropical rain-forest soils., Soil Sci. Soc. Am. J., 66, 834-844, 2002.

Brümmer, C., Brüggemann, N., Butterbach-Bahl, K., Falk, U., Szarzynski, J., Vielhauer, K., Wassmann, R., and Papen, H.: Soil-atmosphere exchange of $\mathrm{N} 2 \mathrm{O}$ and $\mathrm{NO}$ in near-natural savanna and agricultural land in Burkina Faso (W. Africa), Ecosystems, 11, 582-600, 2008.

Brümmer, C., Papen, H., Wassmann, R., and Brüggemann, N.: Fluxes of $\mathrm{CH}_{4}$ and $\mathrm{CO}_{2}$ from soil and termite mounds in south Sudanian savanna of Burkina Faso (West Africa), Global Biogeochem. Cy., 23, GB1001, doi:10.1029/2008GB003237, 2009.

Castaldi, S., Ermice, A., and Strumia, S.: Fluxes of $\mathrm{N}_{2} \mathrm{O}$ and $\mathrm{CH}_{4}$ from soils of savannas and seasonally dry ecosystems, J. Biogeogr., 33, 401-415, 2006.

Chapman, A. L., Sturtz, J. D., Cogle, A. L., Mollah, W. S., and Bateman, R. J.: Farming systems in the Australian semi-arid tropics - a recent history, Aust. J. Exp. Agr., 36, 915-928, 1996.

Chen, X., Eamus, D., and Hutley, L. B.: Seasonal patterns of soil carbon dioxide efflux from a wet-dry tropical savanna of Northern Australia., Aust. J. Bot., 50, 43-51, 2002.

Chen, X., Hutley, L. B., and Eamus, D.: Carbon balance of a tropical savanna of Northern Australia., Oecologia, 137, 405-416, 2003.

Cook, G. D., Williams, R. J., Stokes, C., Hutley, L. B., and Ash, A. J.: Managing sources and sinks of greenhouse gases in Australia's rangelands and tropical savannas, Rangeland Ecol. Manage., 63, 137-146, 2010.

Dalal, R. C. and Allen, D. E.: Greenhouse gas fluxes from natural ecosystems, Aust. J. Bot., 56, 369-407, 2008.

Davidson, E. A., Verchot, L. V., Cattanio, J. H., Ackerman, I. L., and Carvalho, J. E. M.: Effects of soil water content on soil respiration in forests and cattle pastures of Eastern Amazonia, Biogeochemistry, 48, 53-69, 2000.

Del Grosso, S. J., Parton, W. J., Mosier, A. R., Walsh, N. G., Ojima, D. S., and Thornton, P. E.: DAYCENT national-scale simulations of nitrous oxide emissions from cropped soils in the United States, J. Environ. Qual., 35, 1451-1460, 2006.

Dick, J., Skiba, U., Munro, R., and Deans, D.: Effect of N-fixing and non $\mathrm{N}$-fixing trees and crops on $\mathrm{NO}$ and $\mathrm{N}_{2} \mathrm{O}$ emissions from Senegalese soils, J. Biogeogr., 33, 416-423, 2006.

Eamus, D., Hutley, L. B., and O'Grady, A. P.: Daily and seasonal patterns of carbon and water fluxes above a north Australian savanna., Tree Physiol., 21, 977-988, 2001.

Erickson, H., Keller, M., and Davidson, E. A.: Nitrogen oxide fluxes and nitrogen cycling during postagricultural succession and forest fertilization in the humid tropics, Ecosystems, 4, 6784, 2001.

Erickson, H., Davidson, E. A., and Keller, M.: Former land-use and tree species affect nitrogen oxide emissions from a tropical dry forest, Oecologia, 130, 297-308, 2002.
Galbally, I., Meyer, C. P., Wang, Y. P., and Kirstine, W.: Soilatmosphere exchange of $\mathrm{CH}_{4}, \mathrm{CO}, \mathrm{N}_{2} \mathrm{O}$ and $\mathrm{NO}_{\mathrm{x}}$ and the effects of land-use change in the semiarid Mallee system in Southeastern Australia, Glob. Change Biol., 16, 2407-2419, 2010.

Giltrap, D. L., Changsheng, L., and Saggar, S.: DNDC: A processbased model of greenhouse gas fluxes from agricultural soils, Agric. Ecosyst. Environ., 136, 292-300, 2010.

Grace, J., San Jose, J., Meir, P., Miranda, H. S., and Montes, R. A.: Productivity and carbon fluxes of tropical savannas, J. Biogeogr. 33, 387-400, 2006.

Houghton, R. A.: Balancing the global carbon budget, Annu. Rev. Earth Pl. Sci., 35, 313-347, 2007.

Hutchinson, G. L. and Mosier, A. R.: Improved soil cover method for field measurement of nitrous oxide fluxes, Soil Sci. Soc. Am. J., 45, 311-316, 1981.

Hutley, L. B. and Setterfield, S. A.: Savanna, in: Encyclopaedia of Ecology, edited by: Jorgensen, S. E., Elservier, Amsterdam, 2008.

Hutley, L. B. and Beringer, J.: Disturbance and climatic drivers of carbon dynamics of a north Australian tropical savanna, in: Ecosystem Function in Savannas: Measurement and Modelling at Landscape to Global Scales, edited by: Hill, M. J. and Hanan, N. P., CRC Press, Boca Raton, 2010.

IPCC: Fourth Assessment Report: Climate Change, 2007.

Isbell, R. F.: The Australian Soil Classification (Revised edition), CSIRO Publishing, Canberra, 2002.

Jamali, H., Livesley, S. J., Grover, S. P. P., Dawes, T. Z., Hutley, L. B., Cook, G. D., and Arndt, S. K.: The importance of termites to the $\mathrm{CH}_{4}$ balance of a tropical savanna woodland of Northern Australia, Ecosystems, 14, 698-709, 2011.

Keller, M., Veldkamp, E., Weltz, A. M., and Reiners, W. A.: Effect of pasture age on soil trace-gas emissions from a deforested area of Costa Rica, Nature, 365, 244-246, 1993.

Li, C.: Quantifying greenhouse gas emissions from soils: Scientific basis and modeling approach, Soil Sci. Plant Nutr., 53, 344-352, 2007.

Livesley, S. J., Kiese, R., Miehle, P., Weston, C. J., ButterbachBahl, K., and Arndt, S. K.: Soil-atmosphere exchange of greenhouse gases in a Eucalyptus marginata woodland, a clover grass and $P$. radiata and E. globulus plantations, Glob. Change Biol., $15,425-440,2009$.

Livesley, S. J., Grover, S. P. P., Hutley, L. B., Jamali, H., ButterbachBahl, K., Fest, B., Beringer, J., and Arndt, S. K.: Seasonal variation and fire effects on $\mathrm{CH}_{4}, \mathrm{~N}_{2} \mathrm{O}$ and $\mathrm{CO}_{2}$ exchange in savanna soils of Northern Australia, Agr. Forest Meteorol., 115, 1440 1452, 2011.

Lucas, S. J., Day, K. J., and Wood, B.: Revised classification of carth soils of the Daly Basin, N.T., Conservation Commission of the Northern Territory, Darwin, 1985.

Petheram, C. and Bristow, K. L.: Towards an understanding of the hydrological factors, constraints and opportunities for irrigation in Northern Australia: a reveiw., CSIRO13/08, 2008.

Prieme, A., Christensen, S., Dobbie, K. E., and Smith, K. A.: Slow increase in rate of methane oxidation in soils with time following land use change from arable agriculture to woodland, Soil Biol. Biochem., 29, 1269-1273, 1997.

Rosenkranz, P., Brggemann, N., Papen, H., Xu, Z., Seufert, G., and Butterbach-Bahl, $\mathrm{K} .: \mathrm{N}_{2} \mathrm{O}$, $\mathrm{NO}$ and $\mathrm{CH}_{4}$ exchange, and microbial $\mathrm{N}$ turnover over a Mediterranean pine forest soil, Biogeo- 
sciences, 3, 121-133, doi:10.5194/bg-3-121-2006, 2006.

Russell-Smith, J., Murphy, B. P., Meyer, C. P., Cook, G. D., Maier, S., Edwards, A. C., Schatz, J., and Brocklehurst, P.: Improving estimates of savanna burning emissions for greenhouse accounting in Northern Australia: limitations, challenges, applications., Int. J. Wildland Fire, 18, 1-18, 2009. von Fisher, J. C., Butters, G., Duchateau, P. C., Thelwell, R. J., and Siller, R.: In situ measures of methanotroph activity in upland soils: A reaction-diffusion model and field observations of water stress., J. Geophys. Res., 114, G01015, doi:10.1029/2008JG000731, 2009.

Woinarski, J. C. Z., Mackey, B., Nix, H. A., and Traill, B.: The nature of Northern Australia: its natural values, ecological processes and future prospects, ANU E Press, Canberra, ACT, 2007. 